\title{
Characterization of non-calcareous "thin" red clay from south-eastern Brazil: applicability in wall tile manufacture
}

\section{(Caracterização de argila vermelha "magra" não calcária do sudeste do Brasil: aplicabilidade na fabricação de revestimento poroso)}

\author{
S.J.G. Sousa, J. N. F. Holanda \\ Grupo de Materiais Cerâmicos - LAMAV-CCT, Universidade Estadual do Norte Fluminense Darcy Ribeiro \\ Av. Alberto Lamego, 2000, Campos dos Goytacazes, RJ 28013-602, Brazil \\ sidnei_rjsousa@yahoo.com.br,holanda@uenf.br
}

\begin{abstract}
In this work the use of "thin" red clay from south-eastern Brazil (Campos dos Goytacazes, RJ) as raw material for the manufacture of wall tile was investigated. A wide range of characterization techniques was employed, including X-ray diffraction (XRD), X-ray fluorescence (XRF), scanning electron microscopy (SEM), grain-size analysis, and thermogravimetric analysis. The wall tile body was prepared by the dry process. The tile pieces were uniaxially pressed and fired between $1080-1180{ }^{\circ} \mathrm{C}$ using a fast-firing cycle. The following technological properties were determined: linear shrinkage, water absorption, apparent density, and flexural strength. The development of the microstructure was followed by SEM and XRD analyses. It was found that the "thin" red clay is kaolinitic type containing a substantial amount of quartz. The results also showed that the "thin" red clay could be used in the manufacture of wall tiles, as they present properties compatible with those specified for class BIII of ISO 13006 standard.
\end{abstract}

Keywords: thin red clay, wall tile, technological properties, microstructure.

\section{Resumo}

Neste trabalho foi investigada a utilização de argila vermelha "magra" do sudeste do Brasil (Campos dos Goytacazes, RJ) como matéria-prima para a fabricação de revestimento poroso. Uma vasta gama de técnicas de caracterização foi utilizada, incluindo difração de raios $X(D R X)$, fluorescência de raios $X$ (FRX), microscopia eletrônica de varredura (MEV), análise granulométrica e análise termogravimétrica. A massa cerâmica para revestimento poroso (azulejo) foi preparada por via seca. As peças de revestimento poroso foram preparadas por prensagem uniaxial e queimadas entre $1080-1180{ }^{\circ} \mathrm{C}$ usando um ciclo de queima rápido. As seguintes propriedades tecnológicas foram determinadas: retração linear, absorção de água, densidade aparente e tensão de ruptura à flexão. O desenvolvimento da microestrutura foi acompanhado por MEV e DRX. Verificou-se que a argila vermelha "magra" é tipicamente caulinitica contendo uma quantidade substancial de quartzo. Os resultados também mostraram que a argila vermelha "magra" pode ser usada na fabricação de revestimento poroso, cujas propriedades obtidas são compatíveis com as especificadas para a classe BIII da norma ISO 13006.

Palavras-chave: argila vermelha magra, revestimento poroso, propriedades tecnológicas, microestrutura.

\section{INTRODUCTION}

Wall tiles are traditional tile materials used in the civil construction and architecture for covering internal walls and decorative work [1]. The ISO 13006 Standard Specification for ceramic wall tiles prescribes a value of water absorption capacity $>10 \%$ (class BIII) and a value of flexural strength $\geq 15 \mathrm{MPa}$ for thickness $<7.5 \mathrm{~mm}$ [2]. These values are also in accordance with the European standard (EN 14411 Group BIII) for ceramic tiles. Wall tiles also exhibit peculiar characteristics such as high dimensional stability and low moisture expansion. These products are manufactured using large amounts of clay, carbonate, quartz, and minor amount of talc [3-5]. The clays confer plasticity in the conformation step, high dry mechanical strength, and color [6]. The carbonates are responsible for the high porosity and wide firing temperature range. They also increase thermal expansion coefficient of the wall tiles [7]. Quartz contributes for dimensional and thermal stabilities and talc acts as flux material.

The main factors influencing the tile production are the selection and availability of suitable raw materials and the processing conditions required for the fired wall tiles. These factors fundamentally influence the quality and cost of the final product. In general, two types of clays that are often termed as calcareous clays (Ca-rich clays) and noncalcareous clays (Ca-poor clays), are used in the wall tile production [5]. Both are kaolinitic and illitic clays in nature with free quartz as major impurity. The firing transformations of these types of clays were studied by many investigators [8-14]. In calcareous clays the new phases formed are calcium silicates, aluminosilicates, and $\mathrm{Ca}-\mathrm{Mg}$ silicates 
such as wollastonite $\left(\mathrm{CaSiO}_{3}\right)$, larnite $\left(\mathrm{Ca}_{2} \mathrm{SiO}_{4}\right)$, rankinite $\left(\mathrm{Ca}_{3} \mathrm{Si}_{2} \mathrm{O}_{7}\right)$, gehlenite $\left(\mathrm{Ca}_{2} \mathrm{Al}_{2} \mathrm{SiO}_{7}\right)$, anorthite $\left(\mathrm{CaAl}_{2} \mathrm{Si}_{2} \mathrm{O}_{8}\right)$, and diopside $\left(\mathrm{CaMgSi}_{2} \mathrm{O}_{6}\right)$. These clays present a lower (30$60{ }^{\circ} \mathrm{C}$ ) vitrification temperature range due to $\mathrm{Ca}$ and $\mathrm{Mg}$ that act as fluxes [15], and also a more porous structure that remain unchanged about a wide temperature range (100$\left.250{ }^{\circ} \mathrm{C}\right)$. For non-calcareous clays, the most typical high temperature mineral is mullite.

Brazil is currently the second worldwide producer, the second consumer, and fifth exporter of ceramic tiles [16]. This reveals a strong performance of the Brazilian tile industry. In South-Eastern (Campos-RJ), Brazil, there are important non-calcareous sedimentary clay deposits [17-19], which have not been used in the manufacturing of ceramic tiles. There are two main types of sedimentary clays: a high plasticity clay rich in clay minerals, named by the local industry "fat" red clay, and a low plasticity clay rich in silica, named "thin" red clay. Both clays are used for manufacture of clay bricks and roofing tiles. The "fat" red clay has been tested with promising results for red wall tile production [20]. However, the "thin" red clay has not been tested for tile production yet. Thus, the "thin" red clay deposits are of high interest from the technical and economical point of view.

The aim of this work was to study the prospective use of non-calcareous "thin" red clay from the South-Eastern Brazil in the manufacture of red wall tiles. Emphasis is given on the its chemical-mineralogical characteristics, and the physicalmechanical and microstructural characteristics of the fired wall tile pieces. In addition, this work may contribute to valorize the extensive deposits of non-calcareous "thin" red clay from the South-Eastern Brazil (Campos dos Goytacazes, RJ).

\section{MATERIALS AND METHODS}

The following raw materials were used: "thin" red clay, calcareous and quartz. A "thin" red clay sample representative was collected from a quaternary sedimentary deposit located in Campos, RJ, South-Eastern Brazil. Commercial calcareous and quartz were used.

The clay sample was dried at $110{ }^{\circ} \mathrm{C}$ for $24 \mathrm{~h}$, dryground for $2 \mathrm{~h}$, and sieved to pass a $75 \mu \mathrm{m}$ (200 mesh ASTM) sieve. The calcareous and quartz also were sieved to pass a $75 \mu \mathrm{m}$ (200 mesh ASTM) sieve. Mineralogical analysis of the "thin" clay was done by X-ray diffraction (Seifert, model URD 65) with $\mathrm{Cu}-\mathrm{K} \alpha$ radiation on nonoriented clay specimen. The chemical composition of the clay sample was determined by $\mathrm{X}$-ray fluorescence. The loss on ignition was determined at $1100{ }^{\circ} \mathrm{C}$ for $1 \mathrm{~h}$.

The wall tile body formulated consisted of "thin" red clay $(70 \%)$, calcareous $(15 \%)$, and quartz $(15 \%)[4,20]$. The raw materials were mixed during 30 min. using a laboratory cylindrical mixer. The resulting powder sample was granulated in a high intensity mixer (Eirich, type R02) with moisture content of $14 \%$ (moisture mass/dry mass). After reducing the moisture content to $7 \%$, the granulated powder was sieved to eliminate agglomerates larger then $833 \mu \mathrm{m}$ (20 mesh ASTM). The granulated formulation powder was characterized by X-ray diffraction (Seifert URD 65), X-ray fluorescence, thermogravimetric analysis, derivative thermogravimetric analysis, grain size analysis (screening), grinding residue $(<63 \mu \mathrm{m})$, and Hausner ratio. The wall tile pieces were prepared by uniaxial pressing at $35 \mathrm{MPa}$ into rectangular bars of $11.5 \times 2.5 \mathrm{~cm}^{2}$. The formed pieces were then dried for $24 \mathrm{~h}$ at $110{ }^{\circ} \mathrm{C}$. The following properties of the tile pieces in the dry state were determined: linear shrinkage, apparent density, and flexural strength. The firing step was carried out in a fastfiring laboratory kiln (Maitec FSQC-1300/3) at soaking temperatures varying from 1080 to $1180^{\circ} \mathrm{C}$ for a fast-firing cycle of $60 \mathrm{~min}$. total time, including cooling.

The following as-fired technological properties have been determined in accordance with standardized procedures: linear shrinkage, water absorption capacity, apparent density, and flexural strength. Linear shrinkage values upon drying and firing were evaluated from the length variation of the rectangular pieces. Water absorption capacity and apparent density were determined using the Archimedes water displacement method. The flexural strength of the tile pieces (average of five specimens for each value) was measured with a universal testing machine (Instron 1125) in three-point bending tests at a loading rate of $0.5 \mathrm{~mm} / \mathrm{min}$. The flexural strength $(\sigma)$ was calculated by: $\sigma=3 \mathrm{PL} / 2 \mathrm{bd}^{2}$ in which $\mathrm{P}$ is the load of rupture, $\mathrm{L}$ is the distance between supports, $\mathrm{b}$ is the specimen width, and $\mathrm{d}$ its thickness.

The microstructural characterization of the tile pieces was examined via secondary electrons images using a scanning electron microscopy (Zeiss DSM 962) operating at $10 \mathrm{kV}$. Electrical charging was avoided by gold coating on the pieces. The crystalline phases present after firing were identified by $\mathrm{X}$-ray diffraction (Seifert URD-65) with Co-k $\alpha$ radiation, in the $10-60^{\circ} 2 \theta$ range, step $0.05^{\circ}$ and counting time $2 \mathrm{~s}$.

\section{RESULTS AND DISCUSSION}

The chemical composition of the "thin" red clay, presented in Table $\mathrm{I}$, in addition to $\mathrm{SiO}_{2}$ and $\mathrm{Al}_{2} \mathrm{O}_{3}$, shows considerable $\mathrm{Fe}_{2} \mathrm{O}_{3}$. The large proportions of silica and alumina point to the predominance of kaolinite in this kind of clay (Fig. 1). Kaolinite is a two-layer 1:1 silicate and is the principal specimen of its group [5]. It is structurally formed by one layer of silica tetrahedral $\left(\mathrm{SiO}_{4}\right)$, and one layer of octahedral gibbsite, neither bearing cations nor $\mathrm{H}_{2} \mathrm{O}$ molecules between the structural layers. The $\mathrm{SiO}_{2} /$ $\mathrm{Al}_{2} \mathrm{O}_{3}$ ratio of the "thin" clay is of 2.37 , while this ratio for the high plasticity red clays varied between 1.17-1.74 [21]. This indicates that the "thin" red clay possesses more silica in the form of free quartz, thereby resulting in lower plasticity clay. $\mathrm{CaO}$ and $\mathrm{MgO}$ contents indicate that the "thin" red clay used is non-calcareous. The loss on ignition $(9.52 \mathrm{wt} . \%)$ is associated with the presence of clay minerals, hydroxides and organic matter. 


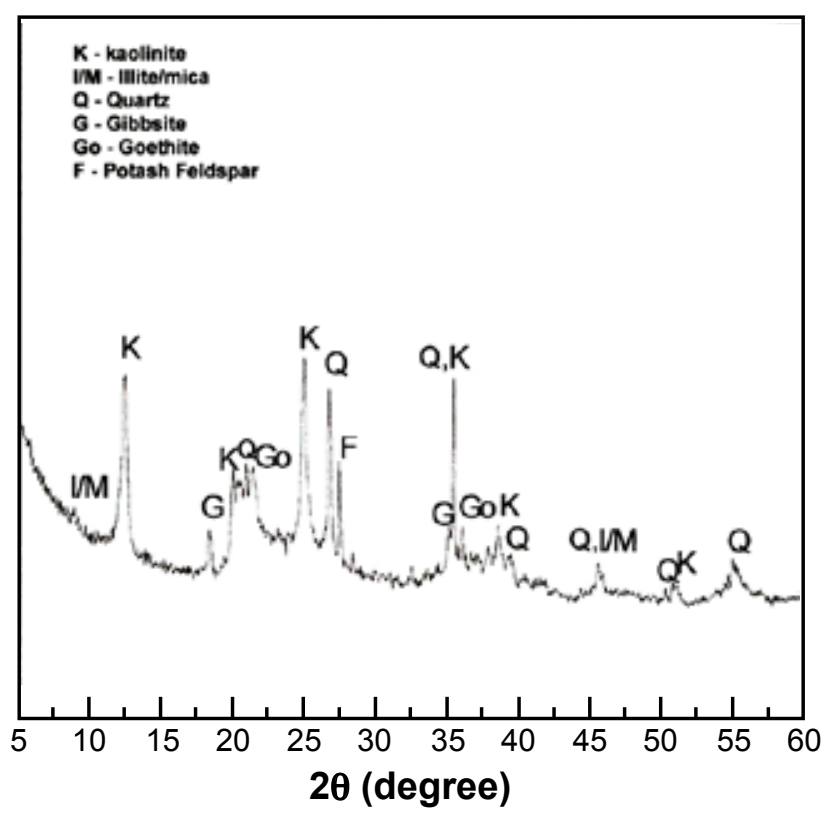

Figure 1: X-ray diffraction pattern of the "thin" red clay.

[Figura 1: Difratograma de raios X da argila vermelha "magra”.]

Table I - Chemical composition of the "thin" red clay (wt.\%). [Tabela I - Composição química da argila vermelha "magra (\% em peso)".]

\begin{tabular}{cc}
\hline $\mathrm{SiO}_{2}$ & 53.45 \\
$\mathrm{Al}_{2} \mathrm{O}_{3}$ & 22.67 \\
$\mathrm{Fe}_{2} \mathrm{O}_{3}$ & 9.05 \\
$\mathrm{Na}_{2} \mathrm{O}$ & 0.57 \\
$\mathrm{~K}_{2} \mathrm{O}$ & 2.02 \\
$\mathrm{CaO}$ & 0.45 \\
$\mathrm{MgO}$ & 0.83 \\
$\mathrm{MnO}$ & 0.09 \\
$\mathrm{TiO}_{2}$ & 1.17 \\
$\mathrm{P}_{2} \mathrm{O}_{5}$ & 0.18 \\
$\mathrm{LoI}$ & 9.52 \\
\hline LoI $=$ loss on ignition
\end{tabular}

The X-ray pattern of the wall tile body (Fig. 2) shows that the main crystalline phases are kaolinite, quartz and calcite. In addition, there are also small amounts of goethite, dolomite, gibbsite, illite/mica and potash feldspar. This result is consistent with the chemical composition of the wall tile body shown in Table II. The loss on ignition at $1100{ }^{\circ} \mathrm{C}$ was $12.68 \%$, which is within the adequate range for wall tile production.

The results of the grain size distribution of the wall tile body (Fig. 3) revealed that the powder granulated by the dry process presented the largest fraction of grains in the 420 and $250 \mu \mathrm{m}$ sizes, with $42.0 \%$ and $35.6 \%$, respectively, followed by the size of $150 \mu \mathrm{m}$ with $15.0 \%$. This indicates that the tile powder is in accordance with the grain size range adequate to obtain good green density during compaction and good reactivity during firing [22].

The tile powder presented reddish color (Table III), which

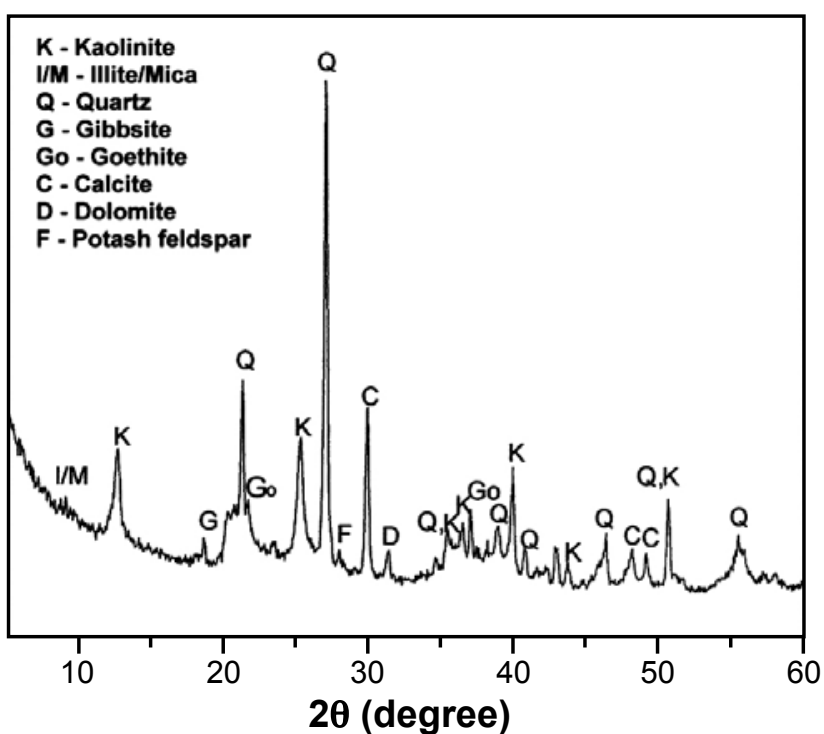

Figure 2: X-ray diffraction pattern of the wall tile body. [Figura 2: Difratograma de raios $X$ da massa de revestimento poroso.]

Table II - Chemical composition of the wall tile body (wt.\%). [Tabela II - Composição química da massa de revestimento poroso (\% em peso).]

\begin{tabular}{cc}
\hline $\mathrm{SiO}_{2}$ & 53.27 \\
$\mathrm{Al}_{2} \mathrm{O}_{3}$ & 16.01 \\
$\mathrm{Fe}_{2} \mathrm{O}_{3}$ & 6.46 \\
$\mathrm{Na}_{2} \mathrm{O}$ & 0.42 \\
$\mathrm{~K}_{2} \mathrm{O}$ & 1.45 \\
$\mathrm{CaO}$ & 7.37 \\
$\mathrm{MgO}$ & 1.32 \\
$\mathrm{MnO}$ & 0.06 \\
$\mathrm{TiO}_{2}$ & 0.83 \\
$\mathrm{P}_{2} \mathrm{O}_{5}$ & 0.14 \\
$\mathrm{LoI}$ & 12.68 \\
\hline \multicolumn{2}{l}{ LoI $=$ loss on ignition }
\end{tabular}

is due to the high amount of iron oxide (Table I). The real density $\left(2.75 \mathrm{~g} / \mathrm{cm}^{3}\right)$ of the material reflects its mineralogical composition (Fig. 2). The Hausner ratio is associated to the flowability of the powder. Flowable powders fill the dies faster and more uniformly. The granulated powder presents a Hausner ratio of 1.26 , which is within the adequate range of granulated powders prepared with the dry process. The tile powder presented a grinding residue $(<63 \mu \mathrm{m})$ of the primary particles of $2.08 \%$. This value indicates a good comminution degree, which favors the reactivity during the firing step [23].

Thermogravimetric analysis (TGA) and derivative thermogravimetric analysis (DrTGA) curves for the red wall tile body are shown in Fig. 4. Four endothermic events are seen in the DrTGA curve. The first endothermic event (at $55.71{ }^{\circ} \mathrm{C}$ ) concerns to the evolution of the physically adsorbed water by the kaolinite platelets [5]. The second 


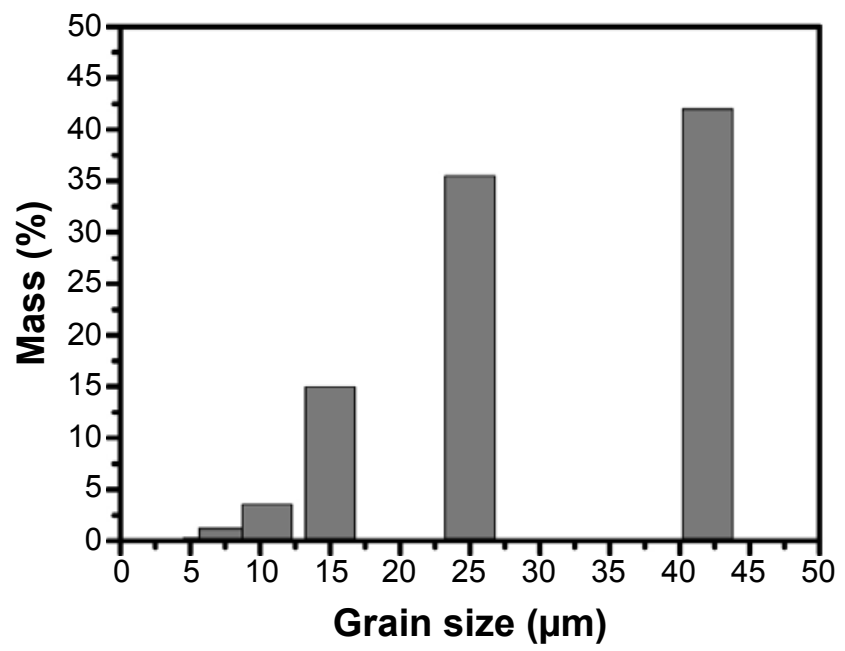

Figure 3: Grain-size distribution of the wall tile powder.

[Figura 3: Distribuição de tamanho de grânulo do pó de revestimento poroso.]

Table III - Physical characteristics of the wall tile powder. [Tabela III - Características físicas do pó de revestimento poroso.]

\begin{tabular}{cc}
\hline Characteristics & Range \\
\hline Color & Reddish \\
Real density $\left(\mathrm{g} / \mathrm{cm}^{3}\right)$ & 2.75 \\
Hausner ratio & 1.26 \\
Grinding residue $(\%)$ & 2.08 \\
\hline
\end{tabular}

endothermic event (at $301.16{ }^{\circ} \mathrm{C}$ ) occurs due to the evolution of water vapor, resulting from the dehydration of hydroxides such as gibbsite and goethite. The third endothermic event (at $549.67{ }^{\circ} \mathrm{C}$ ) is caused by water evolution, but due to dehydroxylation of kaolinite leading to formation of metakaolinite. The four endothermic event (at $791.84{ }^{\circ} \mathrm{C}$ ) is related to the calcareous decomposition to form mainly $\mathrm{CaO}$ and $\mathrm{CO}_{2}$ degassing. However, the

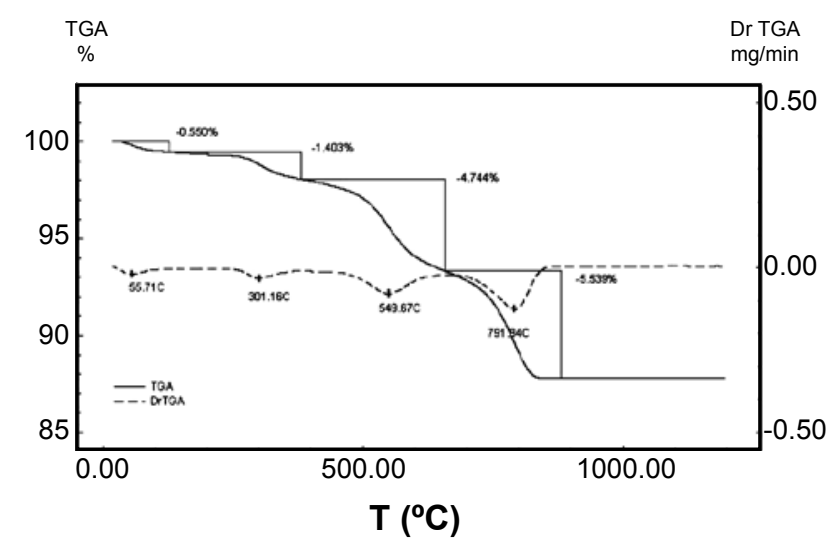

Figure 4: Thermogravimetric and differential thermogravimetric curves for the wall tile body.

[Figura 4: Curvas termogravimétrica e derivativa termogravimétrica para a massa de revestimento poroso.] calcareous used is rich in calcite $\left(\mathrm{CaCO}_{3}\right)$ with dolomite and quartz as main impurities. Thus, decomposition reactions appear to occur simultaneously, resulting in $\mathrm{CaO}$ and $\mathrm{MgO}$ with predominance of $\mathrm{CaO}$. The endothermic events are accompanied by an intense process of mass transfer. Thermogravimetric analysis shows a total weight loss of $12.24 \%$.

The X-ray diffraction patterns of the tile pieces fired at different temperatures (Fig. 5) show that at $1080{ }^{\circ} \mathrm{C}$ the crystalline phases found were wollastonite, gehlenite, anorthite, hematite, and quartz. This phase composition is similar to that formed in wall tiles made of non-calcareous high plasticity clay, except wollastonite [20]. Hematite appears due to the iron oxide present in the "thin" red clay used. It was also found indication of the presence of primary mullite. In firing process of carbonate bearing tile bodies, however, the preferential sequence of reactions is given by: metakaolinite-gehlenite-anorthite $[10,12,13]$. The layered structures of metakaolinite and gehlenite look very similar and therefore the latter phase is more likely to be formed than mullite [13]. Silica and alumina in the reaction transforming metakaolinite into gehlenite come from the collapsed metakaolinite structure, illite, gibbsite and from
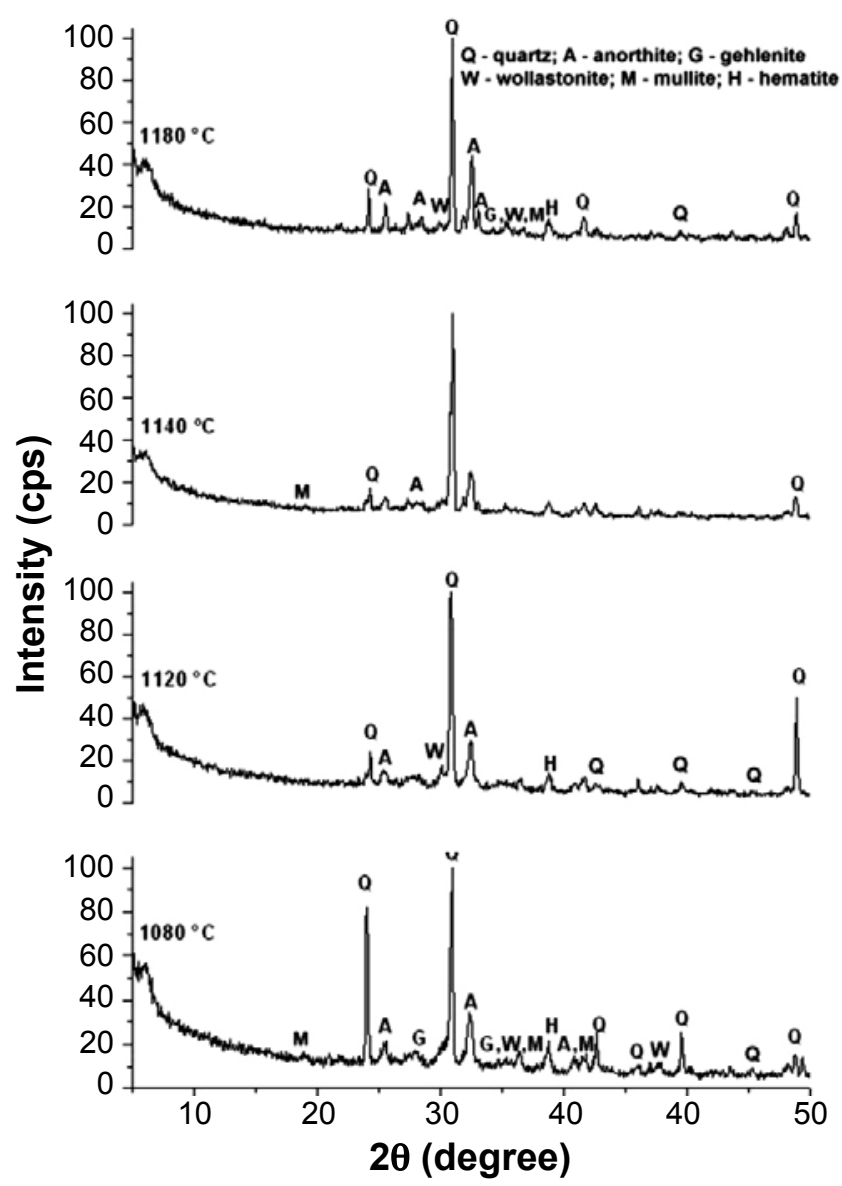

Figure 5: X-ray diffraction patterns of the wall tiles fired at different temperatures.

[Figura 5: Difratogramas de raios $X$ do revestimento poroso queimado em diferentes temperaturas.] 
the remaining fine quartz. Increasing firing temperature up to $1180{ }^{\circ} \mathrm{C}$, originates the increase of anorthite peak intensity and the decrease of quartz peak intensity. This effect is due to quartz partial dissolution, and likely to the reaction among quartz and gehlenite crystals to form anorthite.

Fig. 6 places the wall tile body formulation prepared with the "thin" red clay into the ternary phase diagram $\mathrm{SiO}_{2}-\mathrm{Al}_{2} \mathrm{O}_{3}-\mathrm{CaO}$ [12]. The wall tile body is within the silicaanorthite-wollastonite compatibility triangle. The presence of the gehlenite phase (Fig. 5), however, suggests that the thermodynamic equilibrium was not fully attained during the firing step used in this work. Gehlenite was formed as a metastable intermediate phase between metakaolinite and anorthite. This behavior is typical of fast-firing process used in the ceramic tile industrial production.

The microstructural characterization of the wall tile pieces fired at different temperatures was observed in fractured surfaces after the three-point bending test (Fig. 7ad). The tile structure consists of interconnected pores (open porosity) uniformly distributed in the matrix, and connected
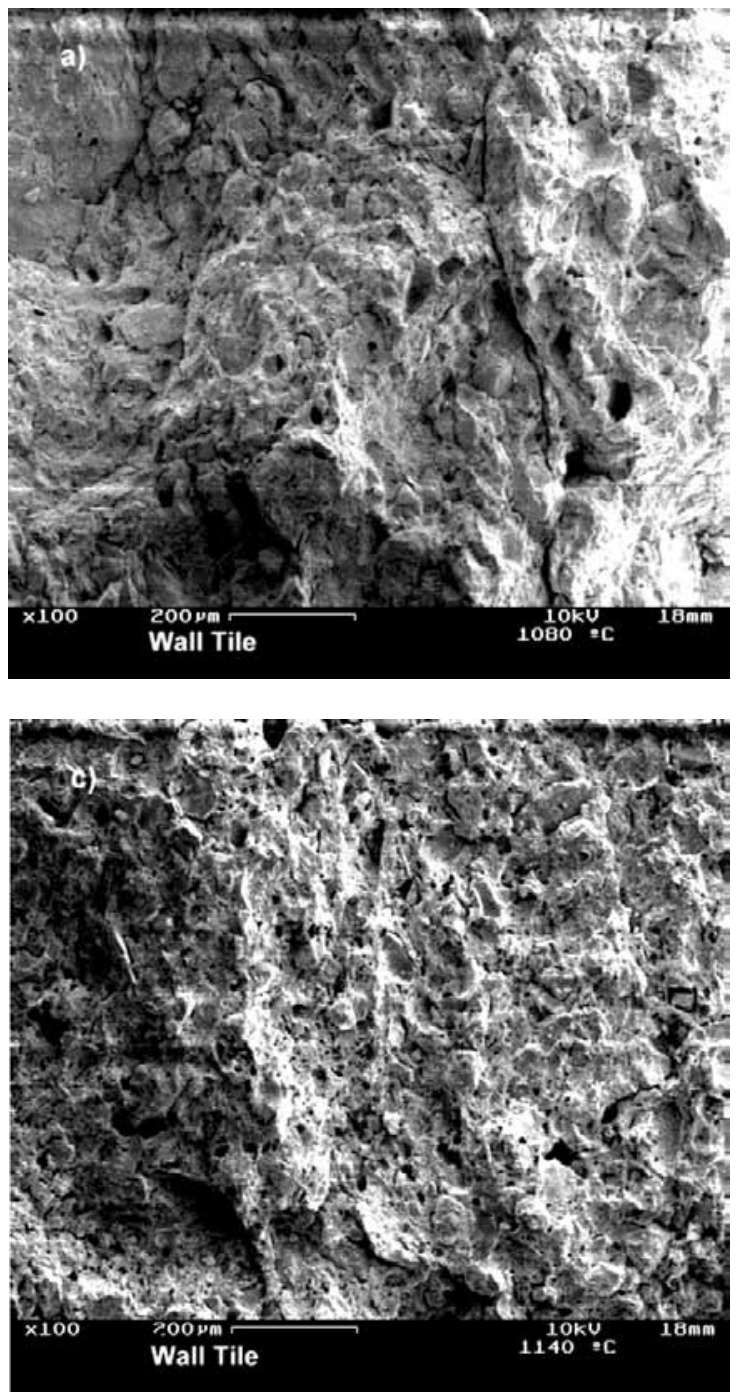

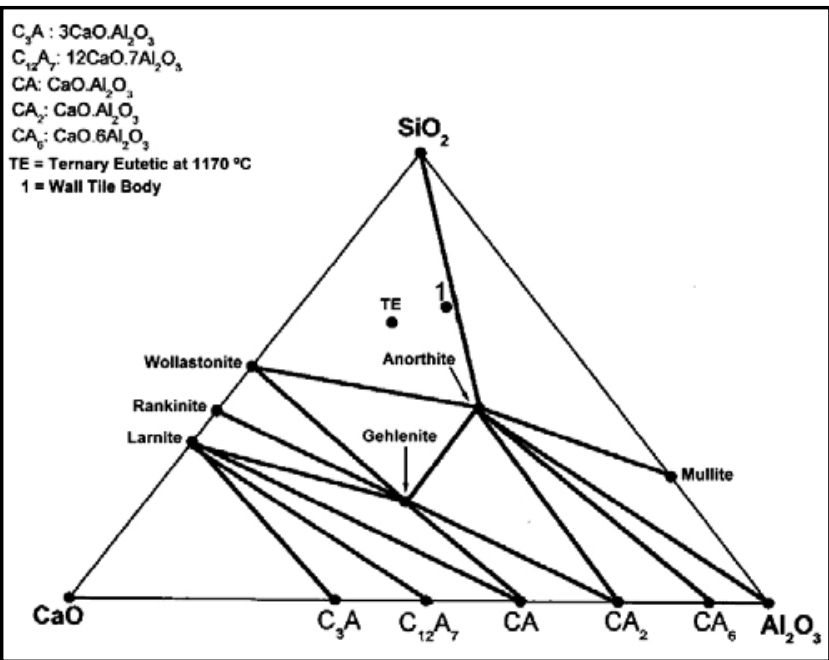

Figure 6: Location of the wall tile body in the $\mathrm{SiO}_{2}-\mathrm{Al}_{2} \mathrm{O}_{3}-\mathrm{CaO}$ phase diagram.

[Figura 6: Localização da massa de revestimento poroso no diagrama de fase $\mathrm{SiO}_{2}-\mathrm{Al}_{2} \mathrm{O}_{3}-\mathrm{CaO}$.]


Figure 7: SEM images of the red wall tiles fired at different temperatures: a) $1080{ }^{\circ} \mathrm{C}$; b) $1120{ }^{\circ} \mathrm{C}$; c) $1140{ }^{\circ} \mathrm{C}$; and d) $1160{ }^{\circ} \mathrm{C}$.

[Figura 7: Imagens de MEV do revestimento poroso queimado em diferentes temperaturas: a) $1080{ }^{\circ} \mathrm{C}$; b) $1120{ }^{\circ} \mathrm{C} ; \mathrm{c}$ ) $1140{ }^{\circ} \mathrm{C}$; e d) $1160{ }^{\circ} \mathrm{C}$. ] 


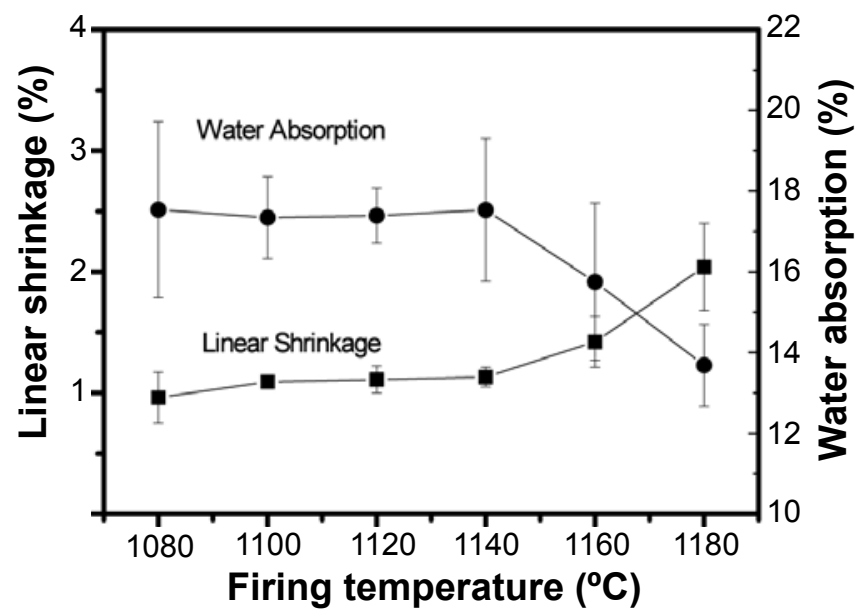

Figure 8: Gresification diagram of the fired tile pieces.

[Figura 8: Diagrama de gresificação das peças de revestimento queimadas.]

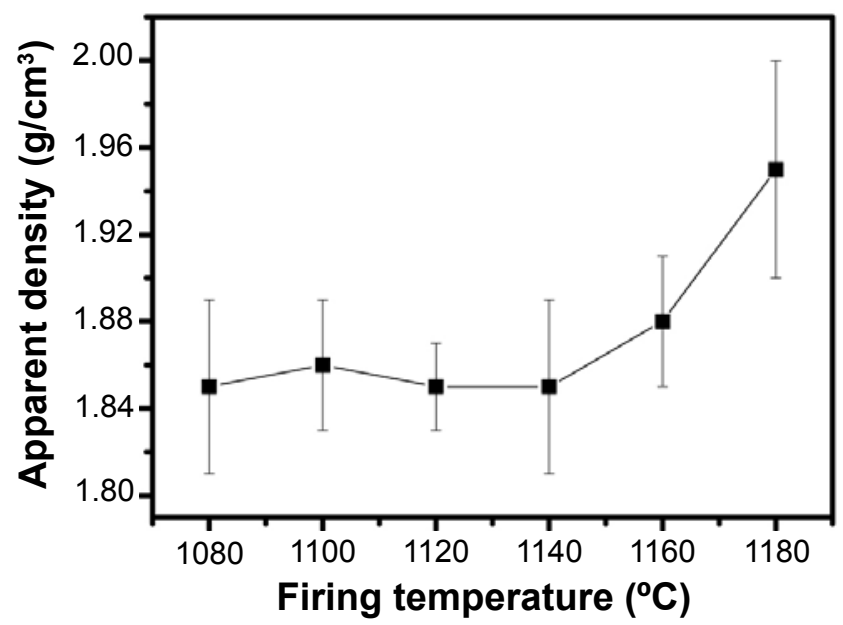

Figure 9: Apparent density as a function of firing temperature. [Figura 9: Densidade aparente como uma função da temperatura de queima.]

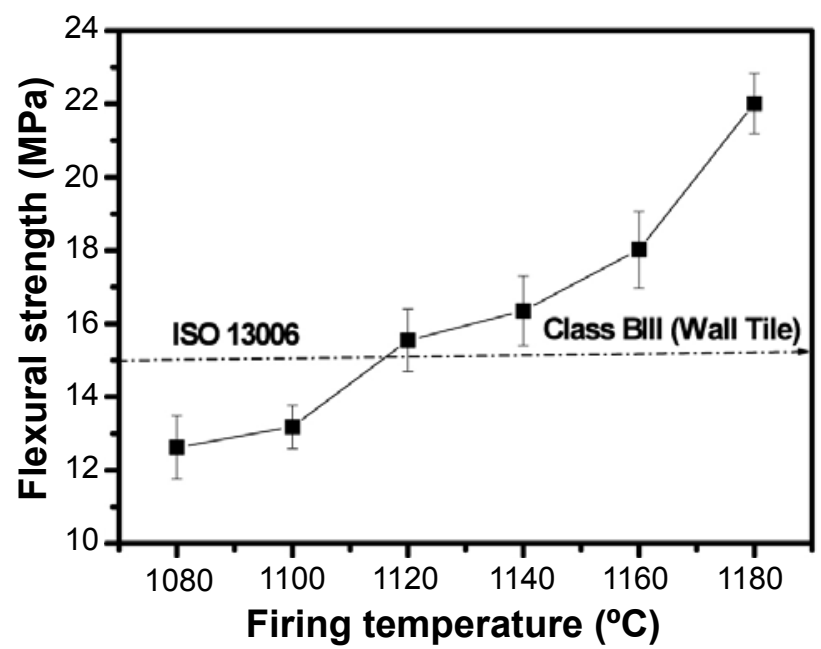

Figure 10: Flexural strength as a function of firing temperature.

[Figura 10: Tensão de ruptura a flexão como uma função da temperatura de queima.] to dense zones (glass filaments). This pore structure is very similar to that observed for wall tile obtained with high plasticity clay [20]. It can also be seen that the porous structure remained unchanged over a wide firing temperature range. The evolution of $\mathrm{CO}_{2}$ from carbonate decomposition can cause the displacement of metakaolinite platelets in decomposition, which creates the open porosity and probably explains the porous structure of the wall tile pieces $[7,15]$. Above $1160{ }^{\circ} \mathrm{C}$ the fractured surface shows a denser, well-sintered structure, that negatively influences the dimensional stability. In addition, this denser structure can make it difficult the escape of $\mathrm{CO}_{2}$ during firing.

In the dried state, the tile pieces showed low linear shrinkage $(0.1 \%)$. In this drying step, it is adequate to obtain a value of linear shrinkage between 0 and $0.3 \%$ in order to avoid cracks, fissures, and warpage [23]. The apparent density of $1.96 \mathrm{~g} / \mathrm{cm}^{3}$ is within the limits for the industrial production of wall tiles. It was also observed that the tile pieces presented drying flexural strength of 4.0 $\mathrm{MPa}$, being acceptable according to the literature [23] that requires value higher than $2.5 \mathrm{MPa}$.

Fig. 8 gives the gresification diagram of the wall tile pieces prepared with "thin" red clay fired at different temperatures. This diagram is very important for determining the optimal firing range of tile materials. It can be seen the wall tile pieces presented a wide firing temperature range. Between $1080^{\circ} \mathrm{C}$ and $1140^{\circ} \mathrm{C}$, the values of linear shrinkage and water absorption are practically constant, in accordance with the microstructural evolution of the samples. This behavior is related to the presence of carbonates mainly calcite $\left(\mathrm{CaCO}_{3}\right)$, which modify the course of reactions at high temperature [1]. The calcium silicate and aluminosilicate-based phases (Fig. 5) formed tend to inhibit the reactions of liquid phase formation. For firing temperatures above $1140{ }^{\circ} \mathrm{C}$, the water absorption capacity (open porosity) gradually decreases and the linear shrinkage of the pieces increases. Between $1080{ }^{\circ} \mathrm{C}$ and $1160{ }^{\circ} \mathrm{C}$, however, the wall tile pieces present good dimensional stability $(0.96-1.42 \%)$. The results also show that all fired pieces present values of water absorption (13.68-17.54\%) above $10 \%$, indicating their conformity to ISO 13006 normative class BIII (porous wall tile) [2].

The results for the apparent density of the fired pieces (Fig. 9) clearly demonstrate the effect of carbonates in retarding the densification during firing. Between $1080{ }^{\circ} \mathrm{C}$ and $1160{ }^{\circ} \mathrm{C}$ the density values of the pieces $\left(1.85-1.88 \mathrm{~g} / \mathrm{cm}^{3}\right)$ are within the limits for the industrial production of wall tiles.

The flexural strength of the wall tile pieces (Fig. 10) increases with increasing firing temperature. This is due to the effective sintering process occurring mainly at higher temperatures. The formation of anorthite (Fig. 5) of high mechanical strength [9], also contributes for higher flexural strength of the wall tile pieces. The results also show that the flexural strength of the pieces fired apart from $1118^{\circ} \mathrm{C}$ was higher than $15 \mathrm{MPa}$, thus indicating they are in accordance with the ISO 13006 normative class BIII. 


\section{CONCLUSIONS}

This work suggests that the wall tile body formulation with non-calcareous "thin" red clay from the south-eastern Brazil fired between 1120-1160 ${ }^{\circ} \mathrm{C}$ presented physicalmechanical properties compatible with those specified for class BIII (porous wall tile) of ISO 13006. The "thin" red clay presented high amount of $\mathrm{SiO}_{2}$, whose $\mathrm{SiO}_{2} / \mathrm{Al}_{2} \mathrm{O}_{3}$ ratio was of 2.37. This has a positive influence on the dimensional stability of the fired wall tile. The results also showed that the carbonate decomposition retarded the sintering process, resulting in wall tile pieces with good dimensional stability (0.96-1.42\%). During firing, the tile body formed calcium silicate and aluminosilicate phases such as wollastonite, gehlenite and anorthite. The decarbonation reactions and consequent liberation of $\mathrm{CO}_{2}$ produced a porous microstructure over a wide firing temperature range, which played an important role in the development of the technological properties of the red wall tile pieces.

\section{ACKNOWLEDGEMENTS}

To CNPq and FAPERJ for financial support.

\section{REFERENCES}

[1] A. Escardino, Tile \& Brick Int 9 (1993) 14-19.

[2] ISO 13006, Ceramic tiles - definitions, classification, characteristics and marking (1998).

[3] C. Fiori, B. Fabbri, G. Donati, I. Venturi, App. Clay Sci. 4 (1989) 461-73.

[4] A. E. Benloch, Tec. Cerám 208 (1993) 740-54.

[5] A. Barba, V. Beltrán, C. Felíu, J. García, F. Ginés, E. Sánchez, V. Sanz, Materias Primas Para la Fabricación de Suportes de baldosas Cerámicas, $2^{\text {nd }}$ Ed., Castellón, ITC (2002).

[6] J. F. M. Motta, M. C. Júnior, L. C. Tanno, A. Zanardo,
Ceram. Ind. 7 (2002) 33-40.

[7] B. E. Yekta, P. Alizadeh, Am. Ceram. Soc. Bull. 75 (1996) 84-86.

[8] T. Peters, R. Iberg, Am. Ceram. Soc. Bull. 57 (1978) 5039.

[9] A. A. Khalil, S. A. El-Korashy, Ceram. Int. 15 (1988) 297-303.

[10] F. González-García, V. Romero-Acosta, G. GarcíaRamos, M. González-Rodríguez, Appl. Clay Sci. 5 (1990) 361-375.

[11] H. El-Didamony, H. H. Assal, H. S. Hasan, N. G. Abd El-Ghafor, Ind. Ceram. 18 (1998) 91-98.

[12] M. M. Jórdan, T. Sanfelíu, C. DeLa Fuente, Appl. Clay Sci. 20 (2001) 87-95.

[13] K. Traoré, T. S. Kabré, P. Blanchat, Ceram. Int. 29 (2003) 377-383.

[14] M. J. Trindade, M. I. Dias, J. Coroado, F. Rocha, Appl. Clay Sci. 42 (2009) 345-355.

[15] M. S. Tite, Y. Maniatis, Trans. Brit. Ceram. Soc. 74 (1975) 19-22.

[16] N. F. Maynard, Brazilian tile industry looks to recover after gloomy 2009. http://www.builderonline.com; 11/2010.

[17] J. Alexandre, F. Saboya, B. C. Marques, M. L. P. Ribeiro, M. G. Salles, M. S. Sthel, L. T. Auler, H. Vargas, The Analyst 124 (1999) 1209-1214.

[18] C. M. F. Vieira, J. N. F. Holanda, D. G. Pinatti, Cerâmica 46, 297 (2000) 15-18.

[19] L. Mota, R. Toledo, F. A. L. Machado, J. N. F. Holanda, H. Vargas, R. T. Faria Jr., Appl. Clay Sci. 42 (2008) 168-174. [20] S. J. G. Sousa, J. N. F. Holanda, Ceram. Int. 31 (2005) 215-222.

[21] G. P. Souza, R. Sanchez, J. N. F. Holanda, Cerâmica 48, 306 (2002) 102-107.

[22] G. Nassetti, G. Brighenti, H. Sillen, Ceram. Acta 4 (1992) 31-44.

[23] A. P. N. Oliveira, Ceram. Ind. 5 (2000) 37-47.

(Rec. 21/02/2011, Ac. 23/03/2011) 